\title{
Civil Society of Modern Russia: Problems of Implementation of Constitutional Rights and Freedoms
}

\footnotetext{
Submitted 18/03/19, 1 st revision 22/04/19, $2^{\text {nd }}$ revision 18/05/19, accepted 03/06/19

A.M. Voronov ${ }^{1}$, M.N. Kobzar-Frolova ${ }^{2}$, V.M. Redkous ${ }^{3}$, A.M. Gogolev ${ }^{4}$

\begin{abstract}
:
Purpose: The aim of this article is to identify problems of legal regulation of the development of civil society in modern Russia. Tasks: to analyze the position of legal regulation of legal relations, to compare formed legal relations in link "state - public authorities - society person"

Design/Methodology/Approach: The theoretical basis of the study is works of scientists in the field of administrative law and state administration concerning the guarantee of rights and freedoms of citizens by executive power rights. Authors revealed the features, essence, internal relations and the relationship of state policy and society, to identify the role of administrative law and make own view on their essence and content.

Findings: Authors highlight the interconnections between the law and science and disclose the multi-dimensional concept of administration.

Practical implications: Authors' development could be utilized in future developments of Russian legal frameworks at all levels of administration.

Originality/Value: The contribution of the article is the comprehensive analysis of legal norm and clarification of basic concepts of administration.
\end{abstract}

Keywords: Legal relations, legal regulation, security, public administration, services.

JEL Code: A14, K19.

Paper Type: Research article in Special Issue dedicated to Russian Economy.

Section 5: Law, Constitutional, Social.

\footnotetext{
${ }^{I}$ D.Sc. in law, Professor, The Head of the Sector of Administrative Law and Administrative Process, the Chief-researcher of the Institute of the State and Law of Russian Academy of Science, the Expert of Russian Academy of Sciences, Professor, Academy of the MIA of Russia, ORCID: 0000-0002-34333183, Moscow, adminlaw@igpran.ru

${ }^{2}$ D.Sc. in law, Professor, Leading researcher of the Sector of Administrative Law and Administrative Process of the Institute of the State and Law, Russian Academy of Science, Moscow, adminlaw@igpran.ru

${ }^{3}$ D.Sc. in law, Professor, Leading researcher of the Sector of Administrative Law and Administrative Process of the Institute of the State and Law, Russian Academy of Science, adminlaw@igpran.ru ${ }^{4}$ Ph.D. in law, Associate Professor, Director, Perm branch of Financial University under the Government of the Russian Federation, ORCID: 0000-0002-5062-8117, galexey1961@mail.ru
} 


\section{Introduction}

«Perestroika», the collapse of the Soviet Union, formation of a new socially-oriented federal state - the Russian Federation mediated adoption of a new Constitution - the Constitution of the Russian Federation (1993). Article 1 of the Constitution establishes main guidelines (ways) of development of the state: democratic state with Republican form of government, legal one. Principles of the constitutional system of the Russian Federation are based on such principles as democracy, state integrity of the Russian Federation, free elections, unity of the system of state power, etc. The bearer of sovereignty and the only source of power in the Russian Federation is its multi-ethnic people (part 1 of article 3 ). The people carry out their power directly, as well as through public authorities and local self-government bodies (part 2 of article $3)$.

\section{Materials and Methods of Research}

The theoretical basis of the study is works of scientists in the field of administrative law and state administration concerning the guarantee of rights and freedoms of citizens by executive power rights, such as works (Kobzar-Frolova, 2018; Voronov, 2017; Pavlushina, 2003 and others). The article also uses results of a sociological survey conducted by the Center of Technologies of State Administration of the IAEP (Institute of Applied Economic Research) and the Center for Social Political Monitoring of the ISC (Institute of Social Sciences) of the Russian Presidential Academy of National Economics and State Administration of the Russian Federation.

The analysis of the degree of investigation of the topic demonstrated, despite the achievements, that there are many unresolved problems, the Russians do not fully feel themselves protected, and forms and methods used by the executive authorities and local governments in their activities do not sufficiently correspond to modern realities. In this situation, a significant role is given to scientists who see the solution to the problem in creating of a new legal phenomenon - state administration and in the development of a mechanism for its implementation into practice. Separately, it should be noted that representatives of administrative legal science do not pay due attention to new forms that contribute to the implementation of constitutional rights and freedoms of citizens, in particular the emerging in modern Russia legal institution - state administration.

The authors demonstrate their own vision of the development of the state and society, summarize some results in the development of democratic processes of formation of the Russian state. It is also suggested that there are contradictions between interests of private actors and interests of the state, the balance of public and private interests is often disturbed. Administrative law, which is aimed at implementation of tasks set out in the Constitution of the Russian Federation and such a legal institution as state administrating, which is a novel of modern administrative law are designed to neutralize these contradictions. 
In order to achieve the purpose methods were used in the research are: logical, analytical, comparative and legal methods, as well as dialectical methods, methods of synthesis, allowing to reveal the features, essence, internal relations and the relationship of state policy and society, to identify the role of administrative law and make own view on their essence and content.

\section{Results}

The Constitution of the Russian Federation emphasizes the provision that the highest value of the state is the individual, his/her rights and freedoms. Acknowledgment, observance and protection of human and civil rights and freedoms is the duty of the state (Article 2). The Russian Federation is a social state with policy that aimed at creating conditions that ensure a worthy life and free development of the individual (Article 7, part 1).

All this suggests that citizens, realizing their constitutional right to free elections, to democracy, issue mandates to Federal representative (legislative) authorities, representative (legislative) authorities of the subjects of the Russian Federation, top officials of the state and subjects of the Russian Federation and delegate to them their rights to adopt such laws, which should fully reflect interests of civil society (for social benefits, protection, security and other benefits guaranteed by the Constitution of the Russian Federation). At the same time, it is appropriate to note that highest officials of the state and subjects of the Russian Federation, deputies of all levels of power bear personal responsibility before citizens of Russia. The Basic law contains direct instructions that, not only citizens and their associations are obliged to observe the Constitution of the Russian Federation and laws of the Russian Federation, but also state authorities, local governments and their officials (part 2 of Article 15).

Twenty-five years have passed since the national vote and adoption of the Basic law. Russia has embarked to build a social, legal and democratic state. Currently, a system of normative and legal acts is being built to ensure protection and security of rights and freedoms of citizens and organizations, administrative reform aimed at improving state administration is being carried out permanently, forms and methods are being improved to ensure implementation of measures of control (supervision) over observance of law and order.

Interests of the individual and the entire civil society are among priorities in the Constitution of the Russian Federation. Analysis of a quarter of a century of experience in the construction of a new social, legal, democratic state shows that rather great successes have been achieved. The Federal structure of the country has changed radically. The Constitution of the Russian Federation established the competence of the President of Russia as a guarantor of rights and freedoms of a human beings and citizens, while the President of the Russian Federation in the sense of the Basic law does not apply to any branch of government. The administrative reform carried out in Russia changes the structure and system of state executive 
bodies. Many other fundamental strategic provisions that determine Russia's policy in the domestic and foreign markets are being implemented.

The Constitution of the Russian Federation established a new system of Supreme bodies of state power, based on a very clear division of the Legislative (representative), Executive and Judicial branches of government, the President of the Russian Federation became the head of state. Parliament became known as the Federal Assembly of the Russian Federation, the lower House of which is the State Duma, the upper one is the Federation Council. The Executive power is implemented by the Government of the Russian Federation. The constitutional and Supreme courts compose the judicial power of the Russian Federation.

The confederate structure of modern Russia is based on its state integrity, the unity of the system of state power (part 3 of Article 5), therefore, taking mandates from the people, representative bodies form Executive bodies. Federal Executive authorities and Executive authorities of subjects of the Russian Federation form uniform system of Executive power in the Russian Federation (part 2 of Article 77).

Being constitutionally independent, executive power has the main purpose to ensure the implementation of the legislation of the Russian Federation. The government of the Russian Federation pursues a unified state policy in all areas and spheres of public life (part 1 of Article 114), implements measures to ensure rights and freedoms of citizens (paragraph «e» of part 1 of Article 114 of the Constitution of the Russian Federation). The government of the Russian Federation acts based on the Federal Constitutional Law on 17.12.1997 No. 2 - Federal Constitutional Law «On the Government of the Russian Federation» and in pursuance of Federal laws (part 1 of Article 115 of the Constitution of the Russian Federation). It is important to note that neither the Government of the Russian Federation nor other public authorities have the right to impose obligations and encumbrances that are not provided for by Federal law and restrict the constitutional rights and freedoms of citizens. At the same time, the Government of the Russian Federation, the entire system of executive authorities of the Russian Federation and local self-government authorities and their officials have an obligation to implement the laws on the territory of the Russian Federation equally with all citizens and bear responsibility equally with all citizens.

However, as evidenced by the practice of the realization of human and civil rights and freedoms, the Russians do not fully feel protected. The validity of the stated thesis is appropriate to argue with the following factors.

On April 18-27, 2018, the Center of Technologies of State Administration IAEP, the Center for Social Political Monitoring of the ISC of the Russian Presidential Academy of National Economics and State Administration conducted a sociological survey on problems of social security and state control from the perspective of citizens as final beneficiaries (RANEPA, 2018). 
Respondents were citizens of different socio-demographic groups and strata at the age of 18 years and older. The sample size is 1000 people. The result was the calculation of the level of social protection of citizens (life, health, property, personal data, other interests). 76,3\% of respondents faced the need to protect at least from one group of risks (threats) during the past two years. The survey showed that the level of social protection of citizens on average is $30 \%$. Among those who are faced with the need to protect at least from one of the group's risks (threats) is $18.4 \%$ of the population. $32.7 \%$ of respondents did not face the need to protect at least one group of risks (threats) (RANEPA, 2018).

The analysis of this sociological research and many other facts gives grounds to assume that Russians do not feel themselves protected. Legislation of the Russian Federation does not have a complete system of countering modern threats and challenges to the security of civil society, while public authorities are not at the proper level and are not fully productive in taking measures aimed at ensuring implementation of legislation of the Russian Federation. It is important to consider the problem of achieving a balance of public and private interests in the implementation of their powers by public authorities and their officials. In modern Russia, the most urgent problem is realization of subjective constitutional rights by citizens, such as participation of citizens in the management of State Affairs. No less important is the question of how the state provides people with the opportunity to realize this constitutional right.

According to the authors, investigation of these issues is in the sphere of administrative and legal regulation. Undoubtedly, administrative and legal regulation is aimed at ensuring security, defense, protection of human rights and freedoms and society as a whole, achieving a balance of public and private interests in the interaction of the state and society, while administrative law regulates public relations regarding enforcement by public authorities and officials of these authorities of legislation in the territory of the Russian Federation (Kobzar-Frolova, 2018). Purpose (tasks) of public authorities is to direct, provide, regulate, interact, etc. And such tasks are assigned not only to the Executive power (the Government of the Russian Federation), but also to other state bodies having public functions (see. for example, PP. "b", article 114 of the Constitution of the Russian Federation). As already noted, much has been achieved, but more remains to be done. The remnants of the past in the laws and in activity of public authorities and their officials are still heavy. This primarily concerns the doctrinal provisions of law of modern Russia, many of which have not been expressed in normative and legal acts. In our opinion, today, or rather yesterday, the modernization of doctrines was required, considering the realities of today, when the architecture of a social, legal, democratic state is being built and formed.

\section{Discussion}

According to the opinion of Professor Yu.A. Tikhomirov (Lazarev Readings, 2018), science should go ahead of the legislator, answering a question that has not yet been 
answered. He noted that the administrative law to date, "dances a solo dance", that is, it develops itself, building at times some chimeric classifications while not moving forward. And it should influence the legislation. Administrative law should permeate with its content all branches of law including into regulation of other industries». As early as 1928, the American scientist E. Freund wrote that «administrative law is a right that controls the administration, not a right created by the administration» (Freund, 1928). With this approach, in connection with the fundamental changes in the concept of the Basic law, providing for the change of the socialist socio-economic formation to a new democratic one, in our opinion, there is an urgent need to revise the national doctrines of all branches of law of modern Russia.

As a number of scholars rightly point out, modern administrative law is focused on the satisfaction, first of all, of social (public) interests and its purpose is to ensure these interests by legal means (Pavlushina, 2003) in order to provide real opportunities for implementation of human and civil rights and freedoms, to achieve the «public good». Realization of rights, freedoms and legitimate interests of individuals, society and the state, as it is known, is ensured by the legal institutions through activities of public authorities implementing their powers on the basis and in pursuance applicable constitutional, administrative and other legislation of the Russian Federation (Voronov, 2006).

It is appropriate to note that the term «administration» has become firmly established in the theory and practice of state administration. It is used in the context of such socially integrated institutions as: tax, customs administration, legal administration of economics, administration of migration processes, etc. At the same time, scholars investigating problems concerning administrative and legal science do not pay due attention to this phenomenon. It is very unfortunate and, in our opinion, not quite correct. It should be emphasized that the term «administration» is primarily of administrative and legal nature. In this regard, an administrative scientist should develop its content, improve forms and methods of activity of the state administration of authorities, thereby expanding the subject of modern administrative law.

\section{Stages of Formation and Development of the Theory of Administration}

Turning to the history of the issue, it should be noted that researches of foreign scientists in the field of public administration, among them were representatives of the American school, founded by Woodrow Wilson create fundamental basis for the investigation of this problem. In 1887, Professor V. Wilson initiated the theoretical development of state administration in his work «The Study of Administration». He stressed that «the science of administration would look for ways to improve activity of authorities, would make their work less time-consuming, would put in order organization of management» (Wilson, 1887).

American political scientist Marshall Dimock in his work «Philosophy of Administration» comes to the conclusion that the modern theory of state 
administration is «a new scientific synthesis that had the necessary relation to all areas of knowledge and all issues that were included into implementation of official policies and programs» (Marshall Dimock, 1978).

It is necessary to agree with Vasilenko (2001) that in Russia, the science of state administration has received official recognition quite recently. In the period of Marxist-Leninist ideology domination the state administration was considered from the point of view of «the leading and directing role of the party». That is why in the years of domination of the party nomenclature the science of state administration was simply not needed. It was considered to be «bourgeois», obviously false. The principles and methods of state administration in the West were interpreted mainly in a negative and critical aspect, which was explained by the general ideological attitudes of past years. In fact, achievements of world public opinion in the field of state administration in Russia are still little known, since works of leading Western scientists have not yet been translated into Russian (Vasilenko, 2001).

In this connection, in our opinion, it is so important today to investigate and summarize the experience of development of world science in the field of state administration and on its basis to build a domestic scientific school of state administration. An essential block of administration is the block of service (reordinary) relations, that is, such relations in civil society, when the initiative comes from citizens. Building a service social state gives a new impulse for improvement and development of forms and methods of state administration. It is also relevant to note that this legal institution is aimed at the realization of human and civil rights and freedoms, their restoration in case of unlawful acts of public administration officials, defense and protection of their legitimate interests by all possible means, as well as ensuring security, or rather protection of the individual and civil society as a whole.

Undoubtedly, forms and methods of public administration within the framework of this legal institution, in our opinion, will serve as a guarantor of respect for the interests of the individual, protection of his/her rights and freedoms. Administration covers a wide range of legal relations aimed at the implementation of constitutional human and civil rights. The concept of «state administration» is very multifaceted. This activity is carried out by all three branches of government of the Russian Federation and is aimed at implementation of constitutional rights and freedoms of individual and citizen, the interests of society and the state as a whole (Voronov, 2017).

\section{Conclusion}

Meanwhile, in theory and practice there is no legal concept of «public administration», which determines its essence and content, as well as the mechanism for the implementation of state administration. To eliminate this gap, it seems appropriate toinvestiate and develop this legal institution, from the standpoint of administrative law, which will undoubtedly contribute to a common interpretation of 
this legal category, as well as the unification and harmonization of sectoral areas of state administration, will allow to uniformly interpret and implement principles, forms and methods of such activities, while significantly increasing its efficiency. It is proposed to understand the state administration as an organically linked triad, essence of which is the activity of state administration to implement tasks and functions of the state: 1) to serve and satisfy interests of the individual and institutions of civil society; 2) to implement administrative functions of state administration, 3) to protect public order, combat crimes and administrative offenses, as well as to ensure the safety of the individual, civil society and the state.

In addition, it is highly advisable to limit the subject area of legal relations in the field of public administration and state administration. This will be of great methodological importance, as not all executive and administrative activity of the state administration is managerial in nature. So, characteristic subject area of state administration, delimiting it from state management is restoration of illegally violated by representatives of state authorities and their officials of rights both of legal entities and individuals on the basis of the Code of Administrative Procedure of The Russian Federation, while its essence is also determined by reordinary (service) relations for the provision of public services by the executive authorities, arising on the initiative of citizens and so on.

In addition to the managerial functions of state administration, such as formation of socio-economic policy and its development in the future; collection and analysis of information; monitoring of the state of affairs and so on; planning and forecasting; control; supervision; monitoring of the state of affairs, etc., the subject area of state administration is a whole range of relations of reordination - when citizens initiate in public authorities provision to them, according to administrative regulations, any services. In this approach, it is today that administrative law must overcome the management dogma in determining its essence and be understood as an industry that is genetically linked to the practice of protecting human rights by legal means.

In the development of this point, it should be noted that today the relationship between the state and the citizen should be changed, where the state should be given the function of a kind of «service center» for the provision of state services, serving the interests of individual and citizen, and administrative law should be given the function of legal support of such activities.

\section{References:}

Freund, E. 1928. Cases on Administration Law, St. Paul, p. 1.

Kobzar-Frolova, M.N. 2018. Administrative Law as a Branch of Law, Science and Academic Discipline: Modern Representation, Teaching in Law Universities. Legal Education and Science, 7, 6-11.

Lazarev Readings. 2018. Proceedings of the International Scientific and Practical Conference «Lazarev Readings» dedicated to the 100-th anniversary of the birth of the famous 
administrative scientist Elena Viktorovna Shorina, comraid and colleague of B.M. Lazarev, October 25, Moscow, Institute of State and Law of RAS, available online: http://www.igpran.ru/news/4794/.

Marshall, D. 1978. Philosophy of Administration. N.Y., 21.

Pavlushina, A.A. 2003. Protection of Public Interest as a Universal Procedural Form. Journal of Russian Federation Law, 6, 76.

RANEPA. 2018. Official Website of the Center of Technologies of State Administration of IAEP and the Center for Social Political Monitoring of the ISC of the Russian Presidential Academy of National Economics and State Administration. Available online: https://www.ranepa.ru/sobytiya/novosti/centr-socialno-politicheskogomonitoringa-ion-ranhigs-predstavil-itogi-oprosa-ob-emigracionnyh-nastroeniyahrossiyan.

Trump, A.N. 1996. Administrative Law of Foreign Countries. Textbook, Publishing House of Spark, 5 .

Vasilenko, I.A. 2001. Administrative and State Administration in the West: USA, Great Britain, France, Germany, St. Petersburg, 8-12.

Voronov, A.M. 2006. Problems of Theory and Practice of Public security of the Russian Federation. Monograph, Ministry of Internal Affairs of the Russian Federation, AllRussian Scientific-Research Institute, Moscow.

Voronov, A.M. 2017. Administrative Law of Modern Russia. Moscow, Administrative Law and Procedure, 8, 6-12.

Wilson, W. 1887. The Study of Administration. Political Science, Quarterly 2, June, 197. 